\title{
Resenha: Tradução de Lance de Dados de Stéphane Mallarmé, tradução Álvaro Faleiros. São Paulo: Ateliê Editorial, 2014.
}

\section{Marie-Hélène Catherine Torres*}

... sans présumer de l'avenir qui sortira d'ici, rien ou presque un art...

Mallarmé, « Observation » relative au Coup de dés, 1897.

O poeta e tradutor Álvaro Faleiros oferece ao público-leitor de língua portuguesa recente retradução, em edição bilíngue e com valiosos paratextos, de obras de Stéphane Mallarmé. Na edição está incluído o poema emblemático intitulado Um Lance de Dados, um prefácio original do próprio Stéphane Mallarmé, análises introdutórias de sua obra na perspectiva do tradutor, Álvaro Faleiros, e uma apresentação do volume escrita por Marcos Siscar.

O poeta francês Stéphane Mallarmé (1842-1898) começou a publicar seus poemas na revista Le Parnasse contemporain editada na capital francesa na década de 1860, quando se mudou para o interior da França com o objetivo de ensinar inglês nas escolas da região. Dos 21 aos 28 anos o poeta viveu com a família em três cidades: Tournon, Besançon e Avignon. Mallarmé desempenhou um papel fundamental na evolução da literatura no século XX e esteve especialmente voltado para as tendências futuristas e dadaístas, colocando-se entre um dos precursores da poesia concreta. Sua poesia e prosa caracterizam-se pela musicalidade e experimentação gramatical. Um Lance de Dados jamais abolirá o acaso, escolhido para a análise de Faleiros, é um longo poema de versos livres e com tipografia revolucionária.

${ }^{*}$ PGET/UFSC

TradTerm, São Paulo, v. 25, Agosto/2015, pp. 303-309

www. usp.br/tradterm

http:// www. revistas. usp. br/tradterm/index 
ToRReS, M. H. C. - Resenha: Tradução de Lance de Dados de Stéphane Mallarmé, tradução Álvaro Faleiros. São Paulo: Ateliê Editorial, 2014.

"A revista Cosmopolis" em 1897

Un coup de dés jamais n'abolira le hasard de Stéphane Mallarmé (184298) foi publicado em 1897 em páginas simples. Como o diretor da revista não entendia a intenção de Mallarmé, pediu ao autor um prefácio que se inicia da seguinte forma: "Gostaria de que esta nota não fosse lida ou caso fosse percorrida que logo a esquecessem, pois ensina ao leitor hábil, pouca coisa". Composto em versos livres, é um dos primeiros poemas tipográficos da literatura francesa.

Última obra de Mallarmé, Um lance de dados se apresenta como um recomeço da poesia: verso, poema e livro estão sendo questionados juntos. Mas como Mallarmé, poeta profundamente comprometido com a tradição versificada, chegou a um poema avant-garde como Um lance de dados?

Graça à consciência que tem da crise do verso, ele reformula a teoria do verso, reconstruindo-o a partir do verso livre. Dispõe o verso livre na página em dobro, reorganiza a sintaxe por agrupamentos e períodos, e transforma criticamente a alegoria. Desse modo o poeta compôs música com palavras. 0 resultado tipográfico, entretanto, não the foi satisfatório e deixou-o insatisfeito com a forma proposta em uma única página pela revista que conseguiu fazer as coisas pela metade, dizia. Sonhava com outra dimensão, com paginação especial. Daí surgiu o projeto Volland.

O Projeto Volland na Editora Firmain-Didot 1896-1900

Em dezembro de 1896, Ambroise Vollard oferece a Mallarmé a oportunidade de publicar um "livro de arte", prometendo-Ihe que seria "a mais bela edição do mundo."

O livro de grande formato foi concebido para ficar aberto numa mesa. São onze páginas duplas com caracteres "de raro uso", conforme Paul Valéry. Mallarmé dedicou-Ihe cuidado especial, corrigiu todas as várias provas entregues pela Editora Firmin-Didot e comparou-o a uma constelação. Na 
TORRES, M. H. C. - Resenha: Tradução de Lance de Dados de Stéphane Mallarmé, tradução Álvaro Faleiros. São Paulo: Ateliê Editorial, 2014.

véspera de sua morte, em 1898, Mallarmé considera que seu livro não necessitava mais de alterações e correções. O livro, segundo ele, estava pronto para impressão. Porém, "a mais bela edição do mundo" nunca foi editada.

O poema

Ao escrever Um lance de dados (1897), no final de sua vida, Mallarmé colocava um fim às antigas formas poéticas do seu século e orientava, de forma precoce, a poesia do início do século XX. Um lance de dados marcou a história da poesia, introduzindo pela primeira vez o contraste entre a abstração do poema (significado e musicalidade) e sua materialidade (topografia e página em branco).

O poema se estende por onze páginas duplas, reproduz todas as variações tipográficas relativas ao tamanho das letras, opção por minúsculas ou maiúsculas, itálico, e espalha em torno da oração principal uma plêiade de proposições secundárias. Um "Mestre" cujo navio naufragou, antes de ser engolido pelas ondas, se prepara para lançar os dados num último desafio aos Céus desertos. Trata-se de uma alegoria transparente do colapso da era antiga e do surgimento do tempo da incerteza.

A bibliografia crítica sobre Um lance de dados é extremamente heterogênea, em parte devido à disposição tipográfica do poema. A formatação ou mise-en-page é original. Não há versos alexandrinos. A rima é reformulada. Há letras em negrito ou em caixa alta, em itálico com pólice diferentes. Muitas teorias interpretativas surgiram com base em uma edição do poema publicado em 1980 por Tibor Papp e Mitsou Ronat. Afirmavam que o poema inteiro era construído a partir do número doze. Alguns críticos seguem a pista numérica (ou formalista), outros exploram a pista visual, fazendo de Mallarmé uma espécie de precursor de Apollinaire e dos seus caligramas, e outros ainda se limitam a uma leitura em nível semântico. 
ToRReS, M. H. C. - Resenha: Tradução de Lance de Dados de Stéphane Mallarmé, tradução Álvaro Faleiros. São Paulo: Ateliê Editorial, 2014.

No título francês, Un coup de dés jamais n'abolira le hasard, que será traduzido por Haroldo de Campos por Um lance de dados jamais abolirá o acaso, está justamente presente 0 acaso. Mallarmé o explica ao leitor no prefácio: "Pegue um Mestre, coloque-o em um navio que está naufragando e imagine o lance de dados. Ele está nas mãos do destino. É o último desafio que lança ao céu. Mas será ele mais forte do que o acaso?"

\section{A forma do poema}

No poema em página dupla, como o queria Mallarmé, o verso de Um lance de dados neutraliza ou desconstrói sistematicamente a forma de verso regular. O poema desconstrói a métrica tradicional, e sua pedra fundamental, o e átono. Este rigor formal é um dos elementos possíveis para constituir o poema como novo gênero.

Um lance de dados constrói uma métrica de página. Quanto à segmentação, ou seja, uma métrica de palavras, a análise sublinha o caráter muito segmentado de um poema que tem apenas dois períodos. Um lance de dados, conforme o Professor Michel Murat da Universidade de Paris IV, não pode ser $O$ Livro: é um poema em toda a sua dimensão afetiva e existencial do drama. Seu movimento se reflete na disposição na página, triunfo do "acaso". É, portanto, o aspecto visual que predominou a recepção de Um lance de dados na chamada "modernidade".

\section{Descodificando o poema}

Muitos pensadores foram confrontados com o poema de Mallarmé, notadamente, Quentin Meillassoux, filósofo contemporâneo que tinha o desejo de descodificar os versos, as palavras, as sílabas e as letras. Na obra Le Nombre et la Sirène - Un déchiffrage du Coup de dés de Mallarmé, Meillassoux tenta decifrar a mensagem do poema de Mallarmé. Ele teria descoberto que o grande poema testamentário de Mallarmé, J amais un coup de dés n'abolira le hasard, é poeticamente codificado. 0 código seria 707, 
TORRES, M. H. C. - Resenha: Tradução de Lance de Dados de Stéphane Mallarmé, tradução Álvaro Faleiros. São Paulo: Ateliê Editorial, 2014.

correspondendo às 707 palavras do poema até o verbo "sagre", completado pelas sete últimas palavras da moral final do poema: todo pensamento emite um lance de dados, e 707 é o número único, o número perfeito para Mallarmé, ou seja, o número 7, incluindo o zero, simbolizando o nada. 0 código só poderia ser descoberto por acaso, por alguém que contaria as palavras do poema para atingir o divino do acaso. Será por acaso a presença dos números 7 (imagem teológica) e 0 (imagem do nada)? Quem poderia conhecer a realidade poética do autor?

Um lance de dados é um texto total, onde significado e forma se unem para ocupar, segundo uma disposição, uma caligrafia e uma tipografia inventada por Mallarmé. Mallarmé provoca um desenho de letras pela disposição e composição das palavras numa única frase, sem pontuação, que começa assim na tradução de Álvaro Faleiros:

\section{J AMAIS} ETERNAS

\section{AINDA QUE LANÇADO EM CIRCUNSTÂNCIAS}

\section{DO FUNDO DE UM NAUFRÁGIO}

Meillassoux afirma ter decifrado o segredo do poema: Mallarmé queria escrever um livro, o "Livro". Será o "Livro" de uma nova religião?

\section{A tradução estelar de Álvaro Faleiros}

Álvaro Faleiros é o que chamo de "poetradutor" com obra poética própria Coágulos (lluminuras 1995), Amapeando (Nankin 1997), Transes (publicado na França em 2000), o Retirante que virou Presidente (Cordel 2002), Auto do Boi d'Água (Cordel 2003). E como tradutor publicou, entre outros, Latitudes: 9 poetas do Québec (Noroît/ Nankin 2003), O Bestiário, de Guillaume Apollinaire (lluminuras 1995) e Caligramas de Guillaume Apollinaire (Ateliê 2007). 
ToRReS, M. H. C. - Resenha: Tradução de Lance de Dados de Stéphane Mallarmé, tradução Álvaro Faleiros. São Paulo: Ateliê Editorial, 2014.

Faleiros é especialista em poesia de língua francesa, e, especificamente, em Mallarmé, introduzido em tradução no Brasil pelos concretistas. Haroldo de Camposm em um texto intitulado "Das estruturas dissipatórias à constelação: a transcriação do Lance de dados de Mallarmé", vinte anos após a primeira publicação de sua tradução, resume os critérios que adotou em sua transcriação em cinco pontos principais - que ele chama de teoria radical da tradução poética - do Lance de dados a cinco: o nível gráfico, o grafo numerológico, a retomada etimológica, a macrossintaxe e as correspondências semântico-visuais. Álvaro Faleiros, herdeiro da tradução de Haroldo de Campos, 40 anos após sua tradução, "reatualiza a tradição", segundo Marcos Siscar.

Enquanto tradutor, ou melhor, retradutor, no sentido de reapresentação da tradução poética, isto é, apresentar novamente, de outro modo, uma tradução, Faleiros faz uma crítica positiva, segundo expressão de Antoine Berman. Faleiros lembra ao leitor que Haroldo de Campos produziu "lindas melodias soltas", trocou "gouffre", escolhido por Mallarmé segundo um "ensejo aliterativo", por "abîme", cometeu alguns contrassensos e produziu "um conjunto considerável de deformações". Faleiros parece não deixar nada vagar ao acaso

nessas paragens

do vago

em que toda realidade se dissolve

De fato, no nosso entender, Faleiros não precisou de coragem para retraduzir, mas sim de talento de poeta - de poeta-tradutor -, de poetradutor, e mais, de entusiamo intelectual.

vigiando

duvidando

rolando

brilhando e meditando

como poetiza Mallarmé.

TradTerm, São Paulo, v. 25, Agosto/2015, pp. 303-309

www. usp. br/tradterm

http:// www. revistas. usp. br/ tradterm/ index 
ToRres, M. H. C. - Resenha: Tradução de Lance de Dados de Stéphane Mallarmé, tradução Álvaro Faleiros. São Paulo: Ateliê Editorial, 2014.

Faleiros chegou ao que eu chamaria de tradução-CONSTELAÇÃO, atingindo $o$ infinito da arte, o drama do ser, humano, poético.

o poema ficou realmente sublime na tradução de Álvaro Faleiros para quem, "com certeza",

Todo Pensamento emite um Lance de dados

TradTerm, São Paulo, v. 25, Agosto/2015, pp. 303- 309

www. usp. br/tradterm

http:// www. revistas. usp. br/tradterm/ index 